\title{
Trend changes of African airmass intrusions in the marine boundary layer over the subtropical Eastern North Atlantic region in winter
}

\author{
By S. ALONSO-PEREZ ${ }^{1,2 *}$,E. CUEVAS ${ }^{1}$, C. PEREZ ${ }^{3}$, X. QUEROL ${ }^{2}$, J. M. BALDASANO ${ }^{4,5}$, \\ R. DR A XLER ${ }^{6}$ and J. J. DE B USTOS ${ }^{1},{ }^{1}$ Izaña Atmospheric Research Center (AEMET), \\ c/La Marina, $20-6^{a}$ planta, CP 38071-Santa Cruz de Tenerife, Spain; ${ }^{2}$ Institute of Environmental \\ Assessment and Water Research (CSIC), c/Lluis Solé i Sabarís, s/n, CP 08028-Barcelona, Spain; ${ }^{3}$ The Earth Institute \\ at Columbia University, NASA Goddard Institute for Space Studies and International Research Institute for Climate \\ and Society, 2880 Broadway, New York, NY 10025, USA; ${ }^{4}$ Barcelona Supercomputing Center, Nexus II Building, \\ c/Jordi Girona, 29, CP 08024, Barcelona, Spain; ${ }^{5}$ Universidad Politécnica de Cataluña, Diagonal 647, CP 08028, \\ Barcelona, Spain; ${ }^{6}$ Air Resources Laboratory, National Oceanic and Atmospheric Administration, 1315 East West \\ Highway, Silver Spring, MD 20910, USA
}

(Manuscript received 25 February 2010; in final form 23 December 2010)

\begin{abstract}
African dust intrusions in the marine mixing layer of the Eastern North Atlantic subtropical region $\left(23.5^{\circ} \mathrm{N}\right.$ to $\left.35^{\circ} \mathrm{N}\right)$ are favoured in winter when the eastern edge of the Azores High covers Southwestern Europe and North Africa. In situ ground pressure observations and reanalysis from National Centers for Environmental Prediction/National Center for Atmospheric Research (NCEP/NCAR) and European Centre for Medium-Range Weather Forecasts (ECMWF) indicate that the Azores High has strengthened and shifted eastward in winter over the last three decades. This is evidenced by the increase over time of the Madrid-Tenerife Index which is defined as the geopotential height anomaly difference at $1000 \mathrm{mb}$ between Tenerife $\left(28.5^{\circ} \mathrm{N} ; 16.3^{\circ} \mathrm{W}\right)$ and Madrid $\left(40.5^{\circ} \mathrm{N} ; 3.5^{\circ} \mathrm{W}\right)$ in winter and of the African Index which is defined as the residence time over Africa of air mass trajectories entering the subtropical Eastern North Atlantic Ocean. Barcelona Supercomputing Center/Dust Regional Atmospheric Model (BSC-DREAM) dust regional model simulations from 1958 to 2006 were performed, assuming that the soil characteristics of dust sources remained unchanged over time. Simulated winter dust concentration levels are well correlated (0.67) with the available background observations for the 1998-2004 period. The model results show a two-fold increase in winter dust concentrations over the 1980-2006 period with respect to the 1958-1979 period, corresponding to the strengthening and eastward shift of the Azores High.
\end{abstract}

\section{Introduction}

African air mass intrusions exert a significant impact on background aerosol levels over the subtropical Eastern North Atlantic Ocean (from the Tropic of Cancer, $23.5^{\circ} \mathrm{N}$ to $35^{\circ} \mathrm{N}$, see Fig. 1a). African mineral dust particles, with diameters ranging between 0.5 and $75 \mu \mathrm{m}$ (Maring et al., 2003), can be injected to high altitudes in the atmosphere and transported over long distances, even reaching the Caribbean and the Amazonas (Duce et al., 1991; Husar et al., 1997; Moulin et al., 1997; Prospero, 1999; Shinn

\footnotetext{
* Corresponding author.

e-mail: salonsop@aemet.es

DOI: $10.1111 /$ j.1600-0889.2010.00524.x
}

et al., 2000). High mineral dust concentrations can affect human health (Ito et al., 1999; WHO, 2002, 2003; Sultan et al., 2005; Meng and Lu, 2007; Middleton et al., 2008), climate (Aitken, 1880; IPCC, 2001; DeMott et al., 2003; IPCC, 2007), communications due to visibility reduction (Darwin, 1846; Carlson and Prospero, 1972; Consejo Económico y Social de Canarias, 1999), agriculture and livestock (Dorta, 1995) and ocean productivity (Jickells et al., 2005).

The study of long-term trends of mineral dust transport and its relation with climatic variability is of great importance for the further improvement of mid-range and long-range dust events forecasting. Several studies have been performed concerning long-term trends of dust events in Asia (Wang, 2005; Wang et al., 2008), Europe (De Angelis and Gaudichet, 1991), the 

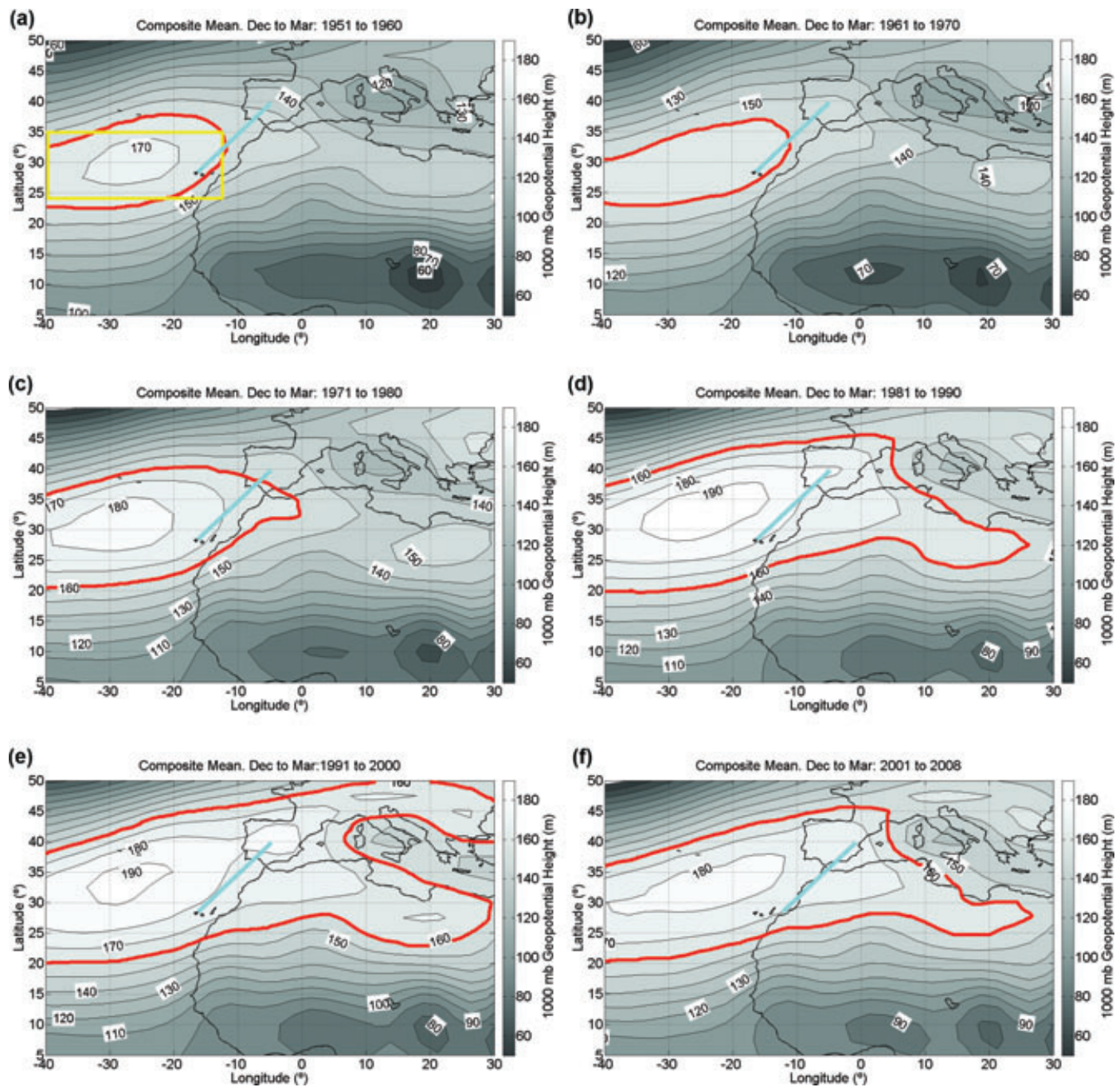

Fig. 1. 1000 mb geopotential height means for the period: (a) 1951-1960, (b) 1961-1970, (c) 1971-1980, (d) 1981-1990, (e) 1991-2000 and (f) 2001-2008 in winter (December-March). The blue line indicates the distance between Tenerife and Madrid. The yellow square indicates the Eastern North Atlantic subtropical region.

Eastern Mediterranean (Ganor et al., 2010), western tropical North Atlantic and Southeastern United States (Prospero, 1999; Prospero and Lamb, 2003; Chiapello et al., 2005; Doherty et al., 2008), West Africa (Evan et al., 2006; Anuforom et al., 2007), North Africa (Mahowald et al., 2010) and North Atlantic (Mahowald et al., 2010), but not focusing in our study region.

In winter, the main dust corridor over the North Atlantic is the tropical belt just off the Sahelian coast (south of $21.25^{\circ} \mathrm{N}$, Prospero et al., 2002). Previous studies of African dust transport to the North Atlantic have focused primarily on tropical latitudes (from $5^{\circ} \mathrm{N}$ to the Tropic of Cancer). Analyses based on surface dust concentrations measured at Barbados since 1965 (Prospero and Nees, 1986; Prospero and Lamb, 2003; Chiapello et al., 2005), as well as other studies (Moulin et al., 1997; Prospero, 1999; Mahowald et al., 2002; Ginoux et al.,
2004; Foltz and McPhaden, 2008; Mahowald et al., 2010), suggest that dust load trends at tropical latitudes could be driven by drought periods in the Sahel, and that there is a significant correlation with the North Atlantic Oscillation (NAO) index in winter.

In this study, we analyse the trends in dust transport over the subtropical Eastern North Atlantic over the past $50 \mathrm{yr}$. Our test site is located on the Island of Tenerife (The Canary Islands; $28^{\circ} 18^{\prime}-28^{\circ} 35^{\prime} \mathrm{N}, 16^{\circ} 07^{\prime}-16^{\circ} 49^{\prime} \mathrm{W}$ ), and situated west (approximately $300 \mathrm{~km}$ ) from the northern coast of Africa (see Fig. 1a). The Canary Islands constitute an excellent site to study the impact of African dust over the subtropical Eastern North Atlantic region (Torres-Padrón et al., 2002; Viana et al., 2002; Alonso-Pérez et al., 2007). In our study region, Tenerife is the island where the longest records of particulate matter 
concentration and ancillary meteorological observations are available. The presence of a Global Atmosphere Watch station of global importance in Tenerife (the Izaña Atmospheric Observatory) corroborates the representativeness of the Canary Islands for atmospheric studies in the subtropical Eastern North Atlantic region.

The most significant dust impacts in the marine mixing layer in the region of interest occur from January to March (AlonsoPérez et al., 2007) when the eastern edge of the Azores High pressure system covers Southwestern Europe and North Africa. The wet and relatively cold marine mixing layer in the subtropical region, in which the atmospheric flow is basically driven by the trade wind regime, is normally limited in its top by a thermal inversion layer, which represents a frontier with the lower free troposphere (very dry and relatively warm). In this paper, we first illustrate the time evolution of the Azores High pressure system through the analysis of the African Index (AFI) and the Madrid-Tenerife index (MTI). Secondly, we have performed long-term simulations with the Barcelona Supercomputing Center/Dust Regional Atmospheric Model (BSC-DREAM) regional dust model to quantify the impact of atmospheric circulation changes, associated to the Azores High, on dust concentrations over the region.

\section{Data and methods}

Total Suspended Particle (TSP) concentrations measured at El Río (ER) station $\left(28^{\circ} 08^{\prime} 35^{\prime \prime} \mathrm{N}, 16^{\circ} 39^{\prime} 20^{\prime \prime} \mathrm{W}, 500 \mathrm{~m}\right.$ a.s.l), located in the subtropical Eastern North Atlantic, are available for the period 1998-2004. ER is a rural background station in Tenerife (Canary Islands) within the marine boundary layer (MBL). The ER station data is used to quantify the influence of the Saharan dust events on the background levels of TSP in the MBL representative of the Eastern North Atlantic subtropical region (Alonso-Pérez et al., 2007).

The AFI was calculated from the NCEP/NCAR reanalysis for the period 1949-2007. The AFI accounts for the percentage of time that an air mass travels over Africa before reaching a receptor site (also called the AFINL 200 index in Alonso-Pérez et al., 2007). Statistically, an increase of AFI values indicates a higher frequency of African air masses, which normally have associated a higher dust concentration in comparison with oceanic air masses. Here, the AFI is calculated from 5-day back-trajectories generated by the Hybrid Single-Particle Lagrangian Integrated Trajectory (HYSPLIT; Draxler and Hess, 1998; Rolph, 2003) model for an end point in Tenerife $\left(28.3^{\circ} \mathrm{N} ; 16.5^{\circ} \mathrm{W}\right)$ at $200 \mathrm{~m}$ a.s.l. In previous studies it has been proved that the AFI, as a first approach, is a good proxy for the frequency of dust-loaded African air masses (Alonso-Pérez et al., 2007; Alonso-Pérez, 2008). In our case, as we focus on an oceanic region where the unique significant dust source is the Sahara, AFI is a simple but effective index for long-term analysis of African dust-loaded air masses.
The NAO index is calculated by taking the difference between the normalized sea level atmospheric pressures between Lisbon, Portugal (the Azores High) and Stykkisholmur, Iceland (the Icelandic Low; Hurrell, 1995). The Jones NAO (JNAO) is defined as the standardized pressure difference between Southwest Iceland and Gibraltar (Jones et al., 1997). These indexes control the strength and direction of westerly winds and storm tracks across the North Atlantic and it has been previously used to study the year-to-year dust variability over the Mediterranean (Moulin et al., 1997; Dayan et al., 2008), and over the North Atlantic in winter (Chiapello and Moulin, 2002; Ginoux et al., 2004; Chiapello et al., 2005) and in summer (Moulin et al., 1997). However, these indexes do not account for the position and shape of the semipermanent Azores High.

A new index, the MTI, is introduced in this study. The MTI is defined as the geopotential height anomaly differences (with respect to the monthly mean values of the period 1961-1990) at $1000 \mathrm{mb}$ between Tenerife and Madrid in winter (December-March). The geographical framework is indicated by a blue line in Fig. 1a. The MTI is really a surrogate of the NAO index, and we have introduced it in this work because it gives a far better account of the intensification of the Azores anticyclone and its zonal elongation on its Eastern flank than the NAO. The MTI tracks better than the NAO the variability of African air masses reaching the marine mixing layer of the subtropical Eastern North Atlantic region.

In this study, we have calculated the MTI from ground pressure recorded at the Tenerife North airport $\left(28.5^{\circ} \mathrm{N} ; 16.3^{\circ} \mathrm{W}\right.$, $617 \mathrm{~m}$ a.s.1.) and at the Madrid-Barajas airport $\left(40.5^{\circ} \mathrm{N} ; 3.5^{\circ} \mathrm{W}\right.$, $582 \mathrm{~m}$ a.s.1.). Unfortunately, although in situ ground pressure records are available at the Tenerife North airport since 1961 only data after 1973 are validated. For this reason, we have computed MTI records from National Centers for Environmental Prediction/National Center for Atmospheric Research (NCEP/NCAR) reanalysis data centred at Tenerife North airport and at Madrid-Barajas airport, respectively, for the period 1949-2007. This is the longest MTI series we can calculate. MTI derived from the European Centre for Medium-Range Weather Forecasts (ECMWF) ERA-40 reanalysis, only available for the 1961-2000 period, has been also computed for comparison and verification purposes. The correlation over the period 1973-2008 between the observed MTI index, and the MTI derived from NCEP reanalysis is very good $(R=0.90)$. The correlation between the MTI from NCEP reanalysis and the MTI from ECMWF reanalysis is excellent $R=0.99$. So, we assume that the 1949-2007 MTI from the NCEP reanalysis series can be used with confidence for our purposes.

On the other hand, the MTI (NCEP)-AFI correlation $(R=$ 0.81 ) over the period $1949-2007$ is significantly better than the NAO-AFI correlation $(R=0.65)$ over the same period. This is in agreement with other results that show that the location of the Azores High is more appropriate to explain the variability of dust transport from Africa over the subtropical 
Atlantic than the NAO as, for example, those from Chiapello et al. (1995) for Cape Verde Islands, and from Riemer et al. (2006) for an area off the Northwest African coast $\left(15^{\circ} \mathrm{N}\right.$ to $30^{\circ} \mathrm{N}$ latitude and $30^{\circ} \mathrm{W}$ to $5^{\circ} \mathrm{W}$ longitude) to the south of our region of interest.

Long-term simulated TSP data for the region bounded by $15^{\circ} \mathrm{N}$ to $45^{\circ} \mathrm{N}$ latitude and $40^{\circ} \mathrm{W}$ to $30^{\circ} \mathrm{E}$ longitude was obtained with the BSC-DREAM (Nickovic et al., 2001). BSC-DREAM provides operational dust forecasts for a broad region covering Northern Africa, Middle East and Europe, and has been intensively tested and verified using available observational data (Perez et al., 2006a,b; Haustein et al., 2009). The TSP data was taken from a 48-yr reanalysis (1958-2006) simulation at $0.3^{\circ} \times$ $0.3^{\circ}$ resolution (Perez et al., 2007) with meteorological fields initialised every $24 \mathrm{~h}$ and boundary conditions updated every $6 \mathrm{~h}\left(2.5^{\circ} \times 2.5^{\circ} \mathrm{NCEP} / \mathrm{NCAR}\right.$ reanalysis $)$.

The BSC-DREAM assumes that no changes in the soil characteristics and vegetation types of grid points acting as dust sources, which are specified using arid and semiarid categories of a global vegetation data set, have occurred over time (Nickovic et al., 2001). High-resolution field of vegetation and soil/texture types are used as input data for the surface process schemes of the atmospheric driving model (NCEP). The assumption of the same global vegetation and soil/texture data set for the complete period is, indeed, a reasonable assumption because the main dust sources that affect the subtropical Eastern North Atlantic (from $25^{\circ} \mathrm{N}$ to $30^{\circ} \mathrm{N}$ ) are located over the Sahara (Alonso-Pérez, 2008), which had a much smaller variation than dust sources located over the northern Sahel (Moulin and Chiapello, 2004) over the past $50 \mathrm{yr}$. This assumption allows us to quantify the impact of changes in atmospheric circulation on dust concentrations over the region. Although we assume that the soil/texture and vegetation types of potential dust sources have not changed within our study period (1958-2006), during the model run, the 'actual' prognostic atmospheric and hydrological conditions are used in order to calculate the effective rates of the injected dust concentration, so dust sources change from day to day depending on wind and soil humidity.

The correlation between average winter (December-March) observed and simulated TSP at ER is $R=0.67$ for the 1998-2004 period.

In order to analyse the trends of AFI, MTI and simulated TSP data series, trend detection was performed with the Linear Regression parametric test, the non-parametric Spearman's rho test (Siegel and Castellan, 1988) and the non-parametric Mann-Kendall test (Manly, 2001). For the determination of the year of the trend change or changes in the means in the annual series, the non-parametric Cumulative Sum of Residuals test (Page, 1954), the Cumulative Deviation parametric test (Buishand, 1982), the Worsley Likelihood Ratio parametric test (Worsley, 1979), the non-parametric Rank sum test (Mann and Whitney, 1947) and the parametric Student's $t$-test (Student, 1908) were used.

\section{Results and discussion}

Former studies (Middleton, 1985; Chiapello et al., 1995; Chiapello and Moulin, 2002; Prospero and Lamb, 2003; Moulin and Chiapello, 2004; Evan et al., 2006) suggest a significant relationship between dust exported towards the North Atlantic region and drought conditions in the Sahel during previous years. For winter (December-March), the correlation between TSP data recorded at ER station and the Sahel Rainfall Index (Janowiak, 1988) of the previous year over the period 1998-2004 is low $(R=0.18)$. Because our simulations assume the soil/texture and vegetation types of the dust sources are constant over time, we cannot assess this hypothesis over the longer term for our study region. In fact, if we use the winter TSP simulated with BSC-DREAM, the correlation is $R=-0.24$ over the 1958-2006 period. However, as stated above, dust sources affecting the subtropical North Atlantic are mainly located over the Sahara (Alonso-Pérez, 2008), where soil characteristics and vegetation types changes have been found to be minor in comparison to those occurred in the Sahel over time (Moulin and Chiapello, 2004).

To quantify the impact of circulation changes (Azores High position and strength) on dust intrusions over the study region, we calculated the $1000 \mathrm{mb}$ geopotential height decadal means (Fig. 1) from NCEP reanalysis data for the period 1950-2007 in the geographic domain $15^{\circ} \mathrm{N}$ to $45^{\circ} \mathrm{N}$ latitude and $40^{\circ} \mathrm{W}$ to $20^{\circ} \mathrm{E}$ longitude. The results show that after 1980 , in winter, the Azores High intensified and presented a more eastwards elongated shape covering the Iberian Peninsula and North Africa with a maximum mean geopotential height of $190 \mathrm{~m}$ during the decades 1981-1990 and 1991-2000 (Figs 1d and e). The incursion of the $160 \mathrm{~m}$ geopotential height contour over Southern Europe and North Africa takes place after 1980. Maps of averaged surface zonal winds for the same periods were also calculated (not shown here). The results are consistent with changes observed in the $1000 \mathrm{mb}$ geopotential height means. Since the 1981-1990 period an enhancement and northward extension of easterlies is observed. A strengthening and eastwards shift of the Azores High favours an enhanced eastern flow and, so, a higher frequency of African air mass intrusions into the marine mixing layer over the subtropical Eastern North Atlantic Ocean (Alonso-Pérez, 2008). This result agrees Moulin et al. (1997) who found that winters with high NAO indices are characterized by a deepening of the Icelandic low associated with a stronger Azores anticyclone. According to Moulin et al. (1997), interannual variations in dust transport over the Atlantic Ocean are well correlated with the climatic variability defined by the NAO because this large-scale climatic control on the dust export is affected through changes in precipitation and atmospheric circulation over the regions of dust mobilization and transport.

We have calculated the trends of the MTI index (1949-2008), which accounts for the zonal elongation of the Azores High (Fig. 2a), the trend of the AFI index (Fig. 2b) for the 1949-2007 
Fig. 2. (a) Seasonal means (winter) of MTI from NCEP reanalysis data (black

diamonds), seasonal means (winter) of MTI from ECMWF reanalysis data (green triangles) and seasonal means (winter) of MTI calculated form observations (white squares), for the period 1949-2007. Red lines indicate lineal trends of MTI from NCEP reanalysis. (b) Seasonal means (winter) of AFI for the period 1949-2007. Red lines indicate linear trends of AFI.
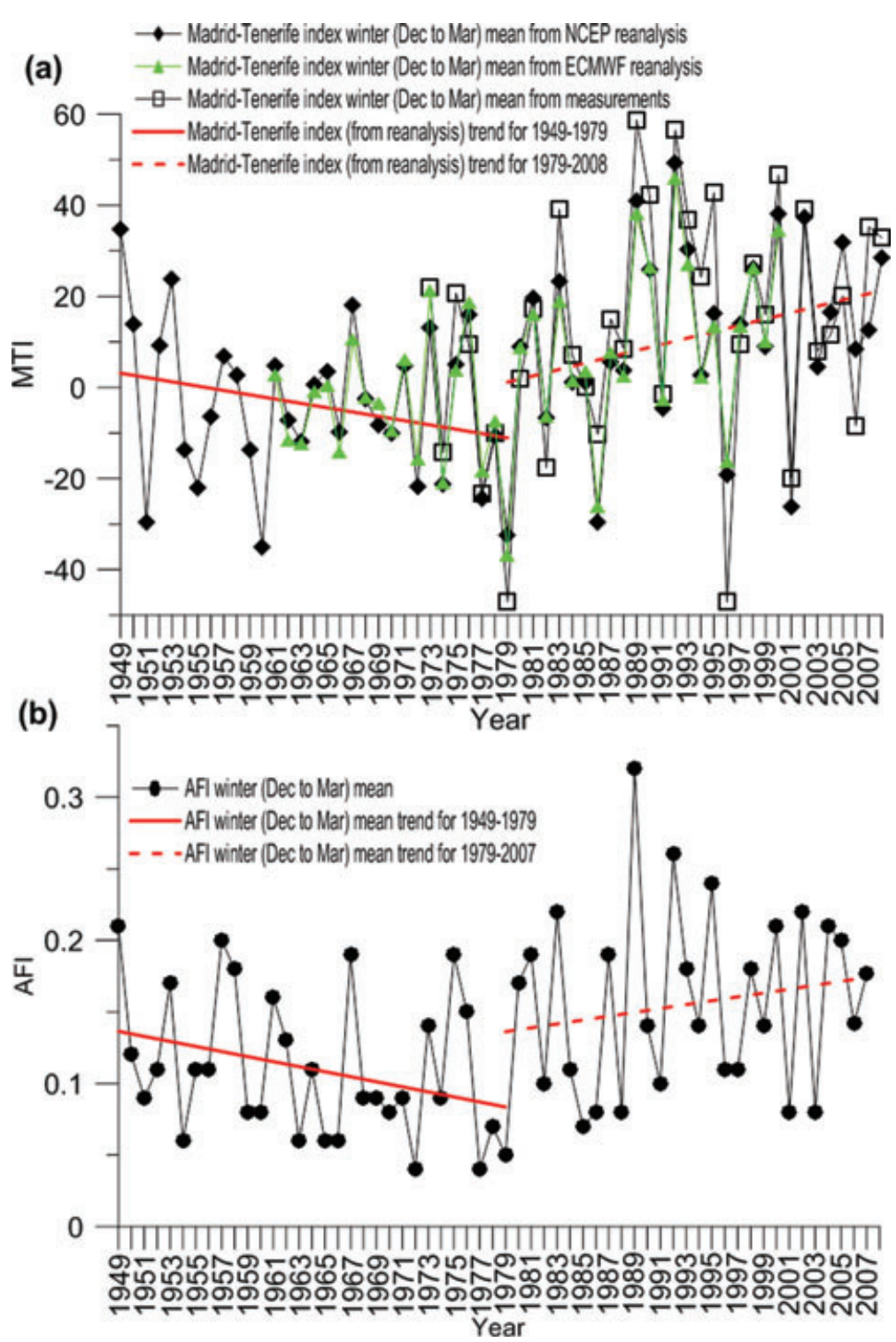

period and the trend of simulated dust concentrations for the 1958-2006 period (Fig. 3). The analysis of the 1949-2008 MTI index winter means series from NCEP reanalysis shows a overall significant increasing trend (at $\alpha<0.01$ significance level). 1979 has been found to be the year of trend change (at $\alpha<0.01$ significance level), from a non-statistically significant negative trend to a statistically significant positive trend (at $\alpha<0.1$ ) in MTI series. This result is consistent with the eastward displacement of the Azores High shown in Fig. 1. The 1949-2007 AFI series (Fig. 2b), which shows a statistically significant positive trend (at $\alpha<0.05$ ), also shows a negative-to-positive trend change after 1979 (statistically significant at $\alpha<0.01$ ), indicating a higher frequency of African air masses reaching the study region (by a factor of 1.41) after 1979. The 1949-1979 AFI series shows a statistically significant negative trend (at $\alpha<0.1$ ). However the
1979-2007 positive trend is not statistically significant (at $\alpha=$ $0.1)$.

The correlation between winter TSP means simulated with BSC-DREAM for the sentinel site (ER station), and both MTI (from NCEP) and AFI means for the period 1958-2006 is $R=$ 0.71 and $R=0.76$, respectively. The analysis of the evolution of simulated winter TSP means denotes a significant overall increasing trend (at $\alpha<0.01$ significance level, Fig. 3). A statistically significant change in means (at $\alpha<0.01$ ) is found after 1980, which is almost coincident with the year of trend change indicated by the analysis of the MTI (from NCEP) and AFI time series (1979). The BSC-DREAM simulation indicates that background averaged TSP concentrations for the testing station approximately doubled (1.8 times) after 1980 in the subtropical Eastern North Atlantic region. 


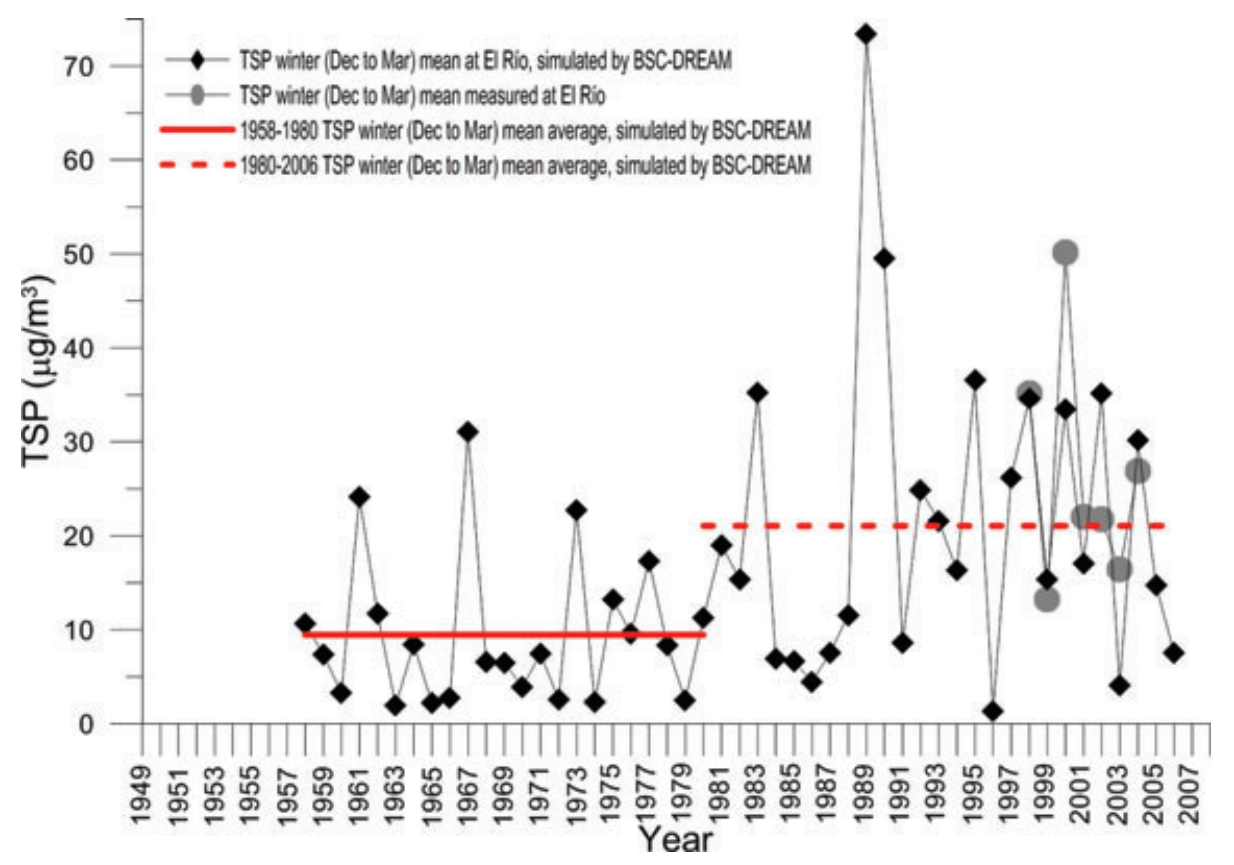

Fig. 3. Winter (December-March) TSP means $\left(\mu \mathrm{g} \mathrm{m}^{-3}\right)$ simulated by the BSC-DREAM for the El Río station for the period $1958-2006$ (black diamonds) and winter TSP means $\left(\mu \mathrm{g} \mathrm{m}^{-3}\right)$ measured at the El Río station for the period 1998-2004 (grey circles). Red lines indicate the average simulated TSP for the 1958-1980 period (solid line) and for the 1980-2006 period (dashed line). The average simulated TSP for the 1958-1980 period is twice the simulated TSP average for the 1980-2006 period.

The plot of simulated winter (December-March) TSP concentrations at ground level for the period 1981-2006 minus those for the period 1961-1980 is shown in Fig. 4 for our study region. This figure clearly demonstrates an increase of dust in Western Sahara and North Mauritania where the main dust sources that affect the Canary Islands and the surrounding subtropical Eastern North Atlantic (between $18^{\circ}$ and $30^{\circ} \mathrm{N}$ ) are located. A TSP increase of about $10 \mu \mathrm{g} \mathrm{m}^{-3}$ over the Canary Islands, and between $2.5 \mu \mathrm{g} \mathrm{m}^{-3}$ and $40 \mu \mathrm{g} \mathrm{m}^{-3}$ over the Western Sahara and North Mauritania is observed. The increase of TSP in winter time after 1980 is consistent with a significant enhancement of easterlies in the same region and time period, as it can be observed from NCEP reanalysis (Fig. 4b). However no significant changes in TSP and surface winds over the rest of the Northern Africa are found. Focusing on the dust anomaly centred at $24^{\circ} \mathrm{N}$ $12.5^{\circ} \mathrm{W}$ we have plotted together the series of the surface TSP $\left(\mu \mathrm{g} \mathrm{m}^{-3}\right)$, simulated with the BSC-DREAM and the series of surface zonal wind component $\left(\mathrm{m} \mathrm{s}^{-1}\right)$, from NCEP reanalysis, over the Saharan dust anomaly for the 1961-2006 period (Fig. 5). As it can be seen in Fig. 5, after 1980 a strengthening of easterlies (higher negative surface zonal wind values) is observed over the dust anomaly. This increase in wind velocity over the dust source might result in an increase of dust mobilization, which is consistent with higher TSP concentrations observed over the dust anomaly in the 1981-2006 period. The surface dust and zonal wind series show a strong negative correlation $(-0.83)$. In order to analyse the relationship between the Azores
High eastward-shift and the increase of dust over the subtropical North Atlantic, we have calculated the wind vector average (at 1000,925 and $850 \mathrm{hPa}$, respectively) of the $10 \mathrm{yr}$ with the highest MTI (1981, 1983, 1989, 1990, 1992, 1993, 1998, 2000, 2002 and 2005, ranging from +9.0 in 1999 to +41.0 in 1989) minus the wind vector average of the $10 \mathrm{yr}$ with the lowest MTI (1963, 1966, 1970, 1972, 1974, 1977, 1979, 1986, 1996, 2001, ranging from -32.4 in 1979 to -9.8 in 1966) in wintertime (December-March) within the 1961-2006 period. As it can be seen in Fig. 6a and b (corresponding to $1000 \mathrm{mb}$ and $925 \mathrm{mb}$, respectively) the wind anomalies have easterly components and the magnitudes over the Western Sahara are larger (around three times) than the anomalies shown in Fig. 4b. The resulting difference wind vector between the high and the low phase of MTI (maximum at $925 \mathrm{mb}$ ) is pointing westward, favouring the export of dust to the subtropical North Atlantic in two different ways. Increasing dust mobilization in the dust source identified on the Western Sahara and North Mauritania and increasing advection of already dusty air masses present over this region. The average of simulated TSP for the ER station for the 10 winters (December-March; 1961-2006) with the highest MTI values is $34.2 \mu \mathrm{g} \mathrm{m}^{-3}$ (maximum at the year 1989 with a value of $73.4 \mu \mathrm{g} \mathrm{m}^{-3}$ ) and the averaged TSP for the 10 winters with the lowest MTI is $5.6 \mu \mathrm{g} \mathrm{m}^{-3}$ (minimum at the year 1996 with a value of $1.4 \mu \mathrm{g} \mathrm{m}^{-3}$ ). The same calculation, performed for the dust source identified on Western Sahara $\left(24^{\circ} \mathrm{N}, 12.5^{\circ} \mathrm{W}\right)$, results in $79.6 \mu \mathrm{g} \mathrm{m}^{-3}$ for the 10 winters with the highest MTI 
(a)

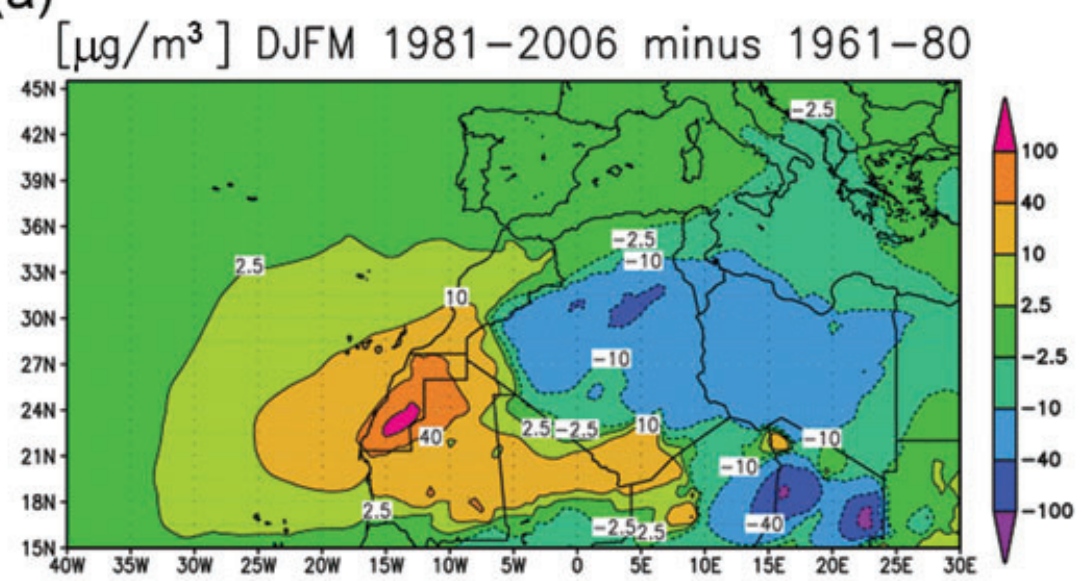

(b) Surface wind vector DJFM 1981-2006 minus 1961-1980

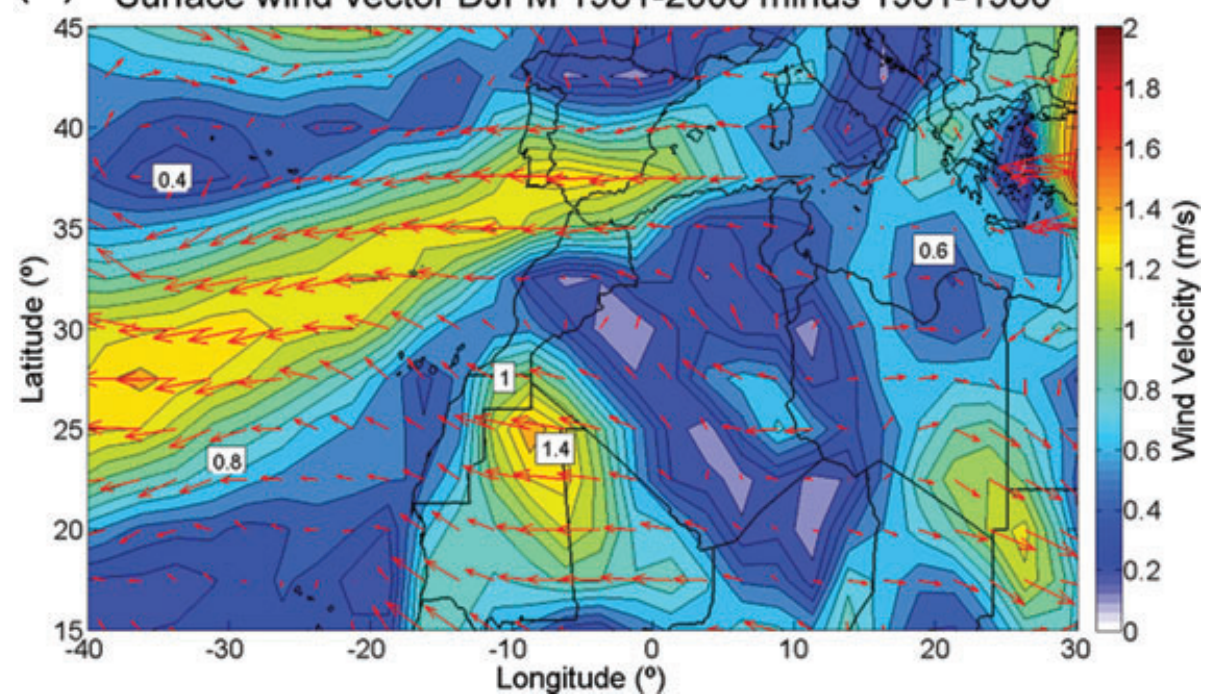

Fig. 4. (a) 1981-2006 minus 1961-1980 winter (December-March) TSP mean concentration at ground level $\left(\mu \mathrm{g} \mathrm{m}^{-3}\right)$ simulated with the BSC-DREAM. (b) 1981-2006 minus 1961-1980 winter (December-March) surface wind vector from NCEP reanalysis.

values (maximum at the year 2000 with a value of $130.8 \mu \mathrm{g} \mathrm{m}^{-3}$ ) and $41.0 \mu \mathrm{g} \mathrm{m}^{-3}$ for the 10 winters with the lowest MTI values (minimum at the year 1966 with a value of $24.5 \mu \mathrm{g} \mathrm{m}^{-3}$ ). These results are quite consistent with the dependence of the wind vector with the MTI.

The TSP and easterlies increment after 1980 coincides with the intensification and eastwards shift of the Azores High. The seasonal correlation (December-March) of MTI with zonal wind at $1000 \mathrm{mb}$ for the $1961-1980$ period is shown in Fig. 7a. A very strong negative correlation is found over the Iberian Peninsula and northwestern Africa. High positive MTI values, observed under strong and eastward shifted Azores High, correspond to lower zonal winds, that is, to an enhancement of the zonal component of the trade flow (stronger easterlies). For the second period (1981-2006), when the Azores High is observed elon- gated to the East, the negative correlation between MTI and the $1000 \mathrm{mb}$ zonal wind is even higher (0.9) over the Saharan dust anomaly (see Fig. 7b). These results agree with Chiapello and Moulin and Chiapello et al. (2005) who suggested that a strong Azores High close to West Africa will enhance the trade winds over the Sahara. Our results also agree quite well with Evan et al. (2006) who found a strong negative correlation between the JNAO and the zonal component of the trade flow across North Africa and into the subtropical North Atlantic.

The important role of the position (in particular the latitude) of the Azores High on dust concentration levels over a broader region of the Atlantic was found in previous studies (Chiapello et al., 1995; Riemer et al., 2006). However, for our region of interest (from the Tropic of Cancer to $35^{\circ} \mathrm{N}$ ), we found that the 


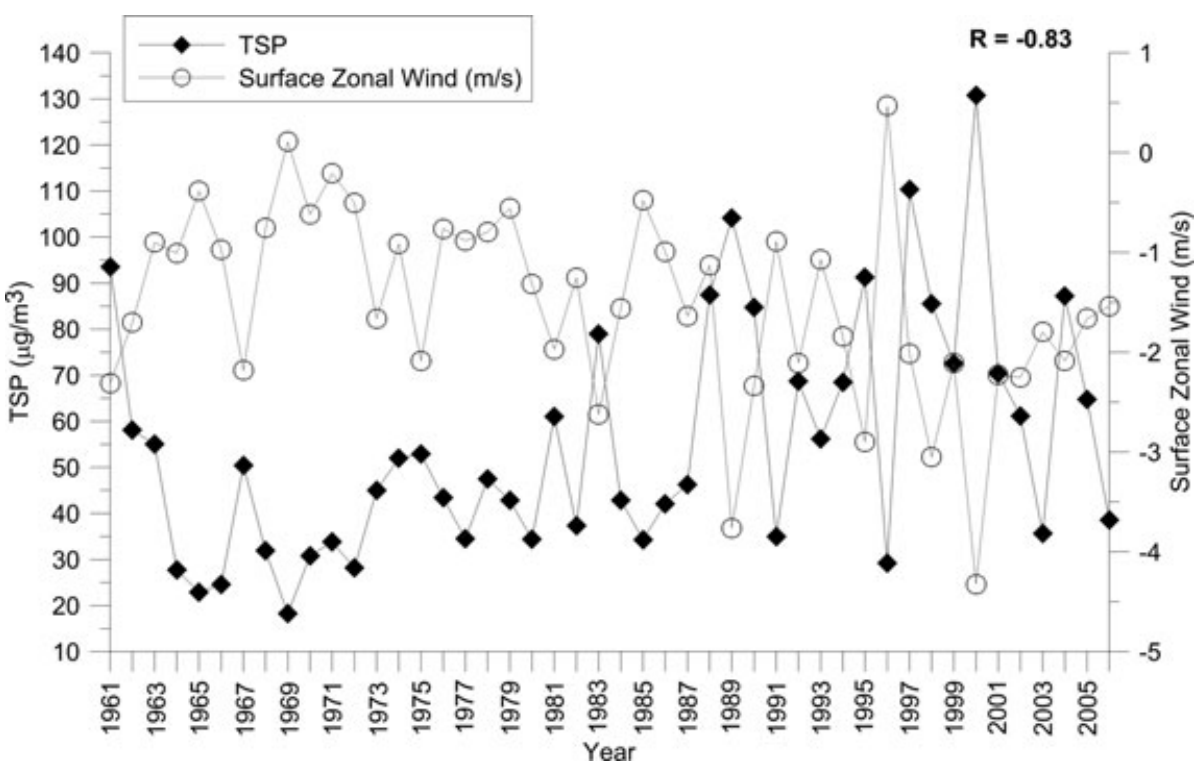

Fig. 5. Winter (December-March) TSP means $\left(\mu \mathrm{g} \mathrm{m}^{-3}\right.$ ) simulated by the BSC-DREAM over $24^{\circ} \mathrm{N}, 12.5^{\circ} \mathrm{W}$ for the period $1961-2006$ (black diamonds) and winter surface zonal wind component $\left(\mathrm{m} \mathrm{s}^{-1}\right)$ from NCEP reanalysis over $24^{\circ} \mathrm{N}, 12.5^{\circ} \mathrm{W}$ for the $1961-2006$ period (circles).

(a)
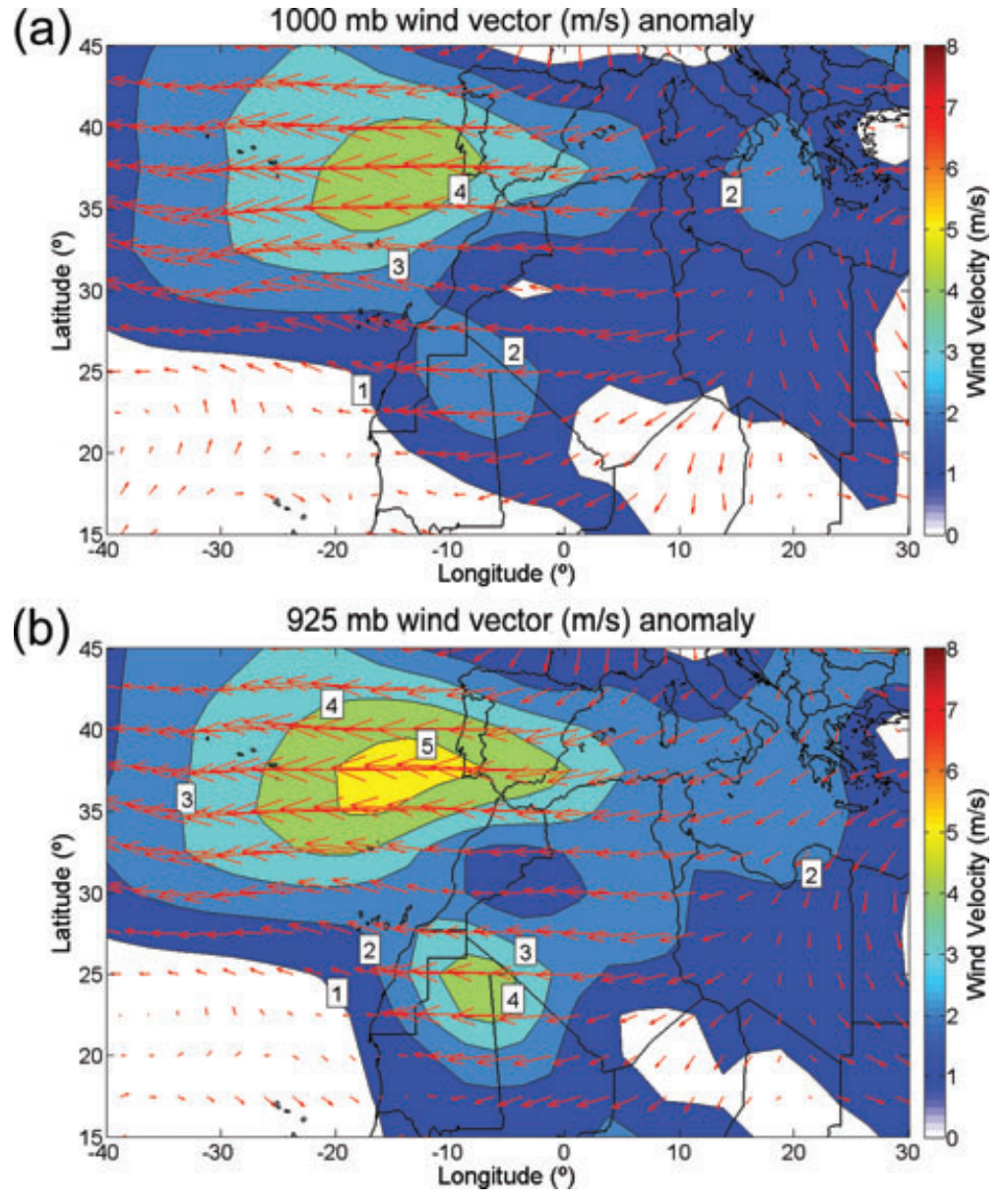

Fig. 6. Wind vector anomaly. Average of the $10 \mathrm{yr}$ with the highest MTI (1981, 1983, 1989, 1990, 1992, 1993, 1998, 2000, 2002 and 2005) minus the average of the $10 \mathrm{yr}$ with the lowest MTI $(1963,1966,1970$, 1972, 1974, 1977, 1979, 1986, 1996 and 2001) in winter (December-March) within the 1961-2006 period for (a) $1000 \mathrm{mb}$ and (b) $925 \mathrm{mb}$. 
Fig. 7. (a) Seasonal correlation (December-March) of MTI with zonal wind at $1000 \mathrm{mb}$ for the $1961-1980$ period. (b) The same as Fig. 6a but for the 1981-2006 period.

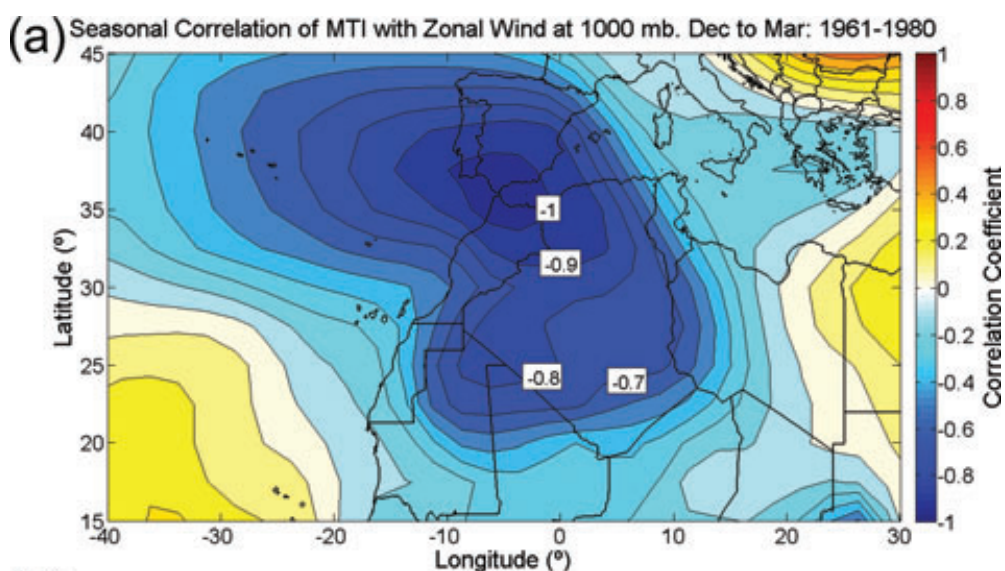

(b) Seasonal Correlation of MTI with Zonal Wind at $1000 \mathrm{mb}$. Dec to Mar: 1981-2006

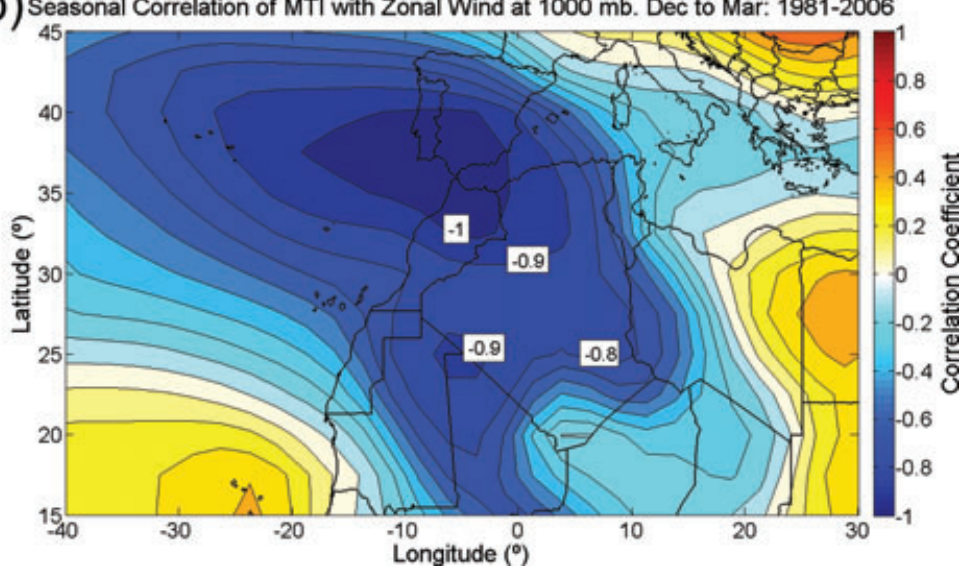

main role is played by the zonal elongation and the intensity of this high.

\section{Conclusions}

In situ observations and analyses of the NCEP/NCAR and ECMWF reanalysis data indicate that the Azores High has intensified and shifted eastwards since the early 1980s, coinciding with more African dust intrusions into the marine mixing layer of the subtropical Eastern North Atlantic region. We have quantified the impact of the Azores High changes over time on dust concentration levels in the region by simulating the TSP time series with the BSC-DREAM at a background rural site (sentinel station) in the study area, which showed a statistically significant (at $\alpha<0.01$ ) concentration increase since 1980. TSP winter mean concentrations simulated with the model for the period 1981-2006 are approximately twice those of the period 1958-1980. An increase of TSP in the MBL over the Subtropical Eastern North Atlantic region in winter after 1980 is consistent with (1) an intensification of the easterly flow in the same period of time, which favours the transport of African air masses into that region and with (2) an enhancement of the dust source located over the Western Sahara-North Mauritania due to an increase of ground winds over this region observed in the same period. The MTI, which accounts for the strength and the eastward displacement of the Azores High, shows a strong negative correlation with the surface zonal wind component over the Northwest Africa for the whole 1961-2006 period. Moreover, a higher negative correlation, especially over the dust anomaly located on the Western Sahara and North Mauritania, is observed for the 1981-2006 period.

\section{Acknowledgments}

The authors thank the NCEP group at NOAA (National Oceanic and Atmospheric Administration) and to the ECMWF for providing reanalysis data. We thank the UNELCO-ENDESA power company and the General Directorate of Industry and Energy of the Canary Government for the El Río TSP data series. The authors also thank two anonymous reviewers for a critical review and helpful suggestions that improved the quality of this paper.

\section{References}

Aitken, J. 1880. On dust, fogs and clouds. Trans. R. Soc. Edinburgh 30, 337-368

Alonso-Pérez, S. 2008. Caracterización de las intrusiones de polvo africano en Canarias. PhD Thesis at the La Laguna University (Tenerife); Centro de Publicaciones de la Secretaría General Técnica 
del Ministerio de Medio Ambiente y Medio Rural y Marino, Madrid, Spain. ISBN: 978-84-8320-473-3.

Alonso-Pérez, S., Cuevas, E., Querol, X., Viana, M. and Guerra, J. C. 2007. Impact of the Saharan dust outbreaks on the ambient levels of total suspended particle (TSP) in the Marine Boundary Layer (MBL) of the Subtropical Eastern North Atlantic Ocean. Atmos. Environ. 41/40, 9468-9480, doi:10.1016/j.atmosenv.2007.08.049.

Anuforom, A. C., Akeh, L. E., Okeke, P. N. and Opara, F. E. 2007. Inter-annual variability and long-term trend of UV-absorbing aerosols during Harmattan season in sub-Saharan West Africa. Atmos. Environ. 41, 1550-1559.

Buishand, T. A. 1982. Some methods for testing the homogeneity of rainfall records. J. Hydrol. 58, 11-27.

Carlson, T. N. and Prospero, J. M. 1972. The large scale movement of Saharan air outbreaks over the northern ecuatorial Atlantic. J. Appl. Meteorol. 11, 283-297.

Chiapello, I., Bergametti, G., Gomes, L., Chatenet, B., Dulac, F. and co-authors. 1995. An additional low layer transport of Sahelian and Saharan dust over the North-Eastern Tropical Atlantic. Geophys. Res. Lett. 22(23), 3191-3194.

Chiapello, I. and Moulin, C. 2002. TOMS and METEOSAT satellite records of the variability of Saharan dust transport over the Atlantic during the last two decades (1979-1997). Geopys. Res. Lett. 29, 17-20.

Chiapello, I., Moulin, C. and Prospero, J. M. 2005. Understanding the long-term variability of African dust transport across the Atlantic as recorded in both Barbados surface concentrations and large-scale Total Ozone Mapping Spectrometer (TOMS) optical thickness. $J$. Geophys. Res. 110, D18S10, doi:10.1029/2004JD005132.

Consejo Económico y Social de Canarias. 1999. Informe anual 1999 del Consejo Económico y Social sobre la situación económica, social y laboral de Canarias en 1998. Available at: http://www. cescanarias.org/publicaciones/informes/infor_1998.html. Last accessed 7 January 2011.

Darwin, C. 1846. An account of this fine dust which often falls on vessels in the Atlantic Ocean. Q. J. Geol. Soc. Lond. 2, 26-30.

Dayan, U., Ziv, B., Shoob, T. and Enzel, Y. 2008. Suspended dust over southeastern Mediterranean and its relation to atmospheric circulations. Int. J. Climatol. 28, 915-924.

De Angelis, M. and Gaudichet, A. 1991. Saharan dust deposition over Mont Blanc (French Alps) during the last 30 years. Tellus 43B, 61-75.

DeMott, P. J., Sassen, K., Poellot, M. R., Baumgardner, D., Rogers, D. C. and co-authors. 2003. African dust aerosols as atmospheric ice nuclei. Geophys. Res. Lett. 30(14), 1372, doi:10.1029/2003GL017410.

Doherty, O. M., Riemer, N. and Hameed, S. 2008. Saharan mineral dust transport into the Caribbean: observed atmospheric controls and trends. J. Geophys. Res. 113, D07211, doi:10.1029/2007JD009171.

Dorta, P. 1995. Algunos efectos de las advecciones de aire cálido sahariano en Canarias. In: Proceedings of the VI Coloquio Ibérico de Geografía. Universidad de Oporto. 833-839.

Draxler, R. R. and Hess, G. D. 1998. An overview of the HYSPLIT_4 modelling system for trajectories, dispersion and deposition. Aust. Met. Mag. 47, 295-308.

Duce, R. A., Liss, P. S., Merrill, J. R., Atlas, E. L., Buat-Menard, P. and co-authors. 1991. The atmospheric input of trace species to the world ocean. Glob. Biogeochem. Cycles 5(3), 193-259.

Evan, A. T., Heidinger, A. K. and Knippertz, P. 2006. Analysis of winter dust activity off the coast of West Africa using a new 24-year overwater advanced very high resolution radiometer satellite dust climatology. J. Geophys. Res. 111, D12210, doi:10.1029/2005JD006336.

Foltz, G. R. and McPhaden, M. J. 2008. Trends in Saharan dust and tropical Atlantic climate during 1980-2006. Geophys. Res. Lett. 35, L20706, doi:10.1029/2008GL035042.

Ganor, E., Osetinsky, I., Stupp, A. and Alpert, P. 2010. Increasing trend of African dust, over 49 years, in the eastern Mediterranean. J. Geophys. Res. 115, D07201, doi:10.1029/2009/2009JD012500.

Ginoux, P., Propero, J. M., Torres, O. and Chin, M. 2004. Long-term simulation of global dust distribution with the GOCART model: correlation with North Atlantic Oscillation. Environ. Model. Softw 19, 113-128.

Haustein, K., Pérez, C., Baldasano, J. M., Müller, D., Tesche, M. and co-authors. 2009. Regional dust model performance during SAMUM 2006. Geophys. Res. Lett. 36, L03812, doi:10.1029/2008GL036463.

Hurrell, J. 1995. Decadal trend in the North Atlantic oscillation: regional temperatures and precipitation. Science 269, 676-679.

Husar, R. B, Prospero, J. M. and Stowe, L. L. 1997. Characterization of tropospheric aerosols over the oceans with the NOAA advanced very high resolution radiometer aerosol optical thickness operational product. J. Geophys. Res. 102, 16 889-16910.

IPCC. 2001. Climate Change 2001: The Scientific Basis. IPPC Cambridge University Press, Cambridge/New York.

IPCC. 2007. In: Climate Change: The Physical Science Basis. Contribution of Working Group I to the Fourth Assessment Report of the Intergovernmental Panel on Climate Change (ed. Solomon, S.). Cambridge University Press, New York.

Ito, K., De Leon, S., Lippmann, M., Nadas, A. and Thurston, G. D. 1999. Final report: an evaluation of confounders in PM10/Mortality associations. Available at: http://cfpub.epa.gov/ncer_abstracts/index.cfm/ fuseaction/display.abstractDetail/abstract/689/report/F. Last accessed 7 January 2011.

Janowiak, J. 1988. An investigation of interannual rainfall variability in Africa. J. Clim. 1, 240-255.

Jickells, T. D., An, Z. S., Andersen, K. K., Baker, A. R., Bergametti, G. and co-authors. 2005. Global Iron connections between desert dust, ocean biogeochemistry, and climate. Science 308(5718), 67-71, doi:10.1126/Science.1105959.

Jones, P., Jünsson, T. and Wheeler, D. 1997. Etensions to the North Atlantic Oscillation using early instrumental pressure observations from Gibraltar and south-west Iceland. Int. J. Climatol. 17, 1433-1450.

Mahowald, N. M., Zender, C., Luo, C., Savoie, D., Torres, O. and coauthors. 2002. Understanding the 30-year Barbados deset dust record. J. Geophys. Res. 107, 4561, doi:10.1029/2002JD002097.

Mahowald, N. M., Kloster, S., Engelstaedter, S., Moore, J. K., Mukhopadhyay, S. and co-authors. 2010. Observed $20^{\text {th }}$ century desert dust variability: impact on climate and biogeochemistry. Atmos. Chem. Phys. Discuss. 10, 12 585-12 628, doi:10.5194/acpd-1012585-2010.

Manly, B. F. J. 2001. Statistics for Environmental Science and Management, Chapman \& Hall/CRC, London. ISBN: 1-58488-029-5.

Mann, H. B. and Whitney, D. R. 1947. On a test of whether one of two random variables is stochastically larger that the other. Ann. Math. Stat. 18, 50-60.

Maring, H., Savoie, D. L., Izaguirre, M. A., Custals, L. and Reid, J. S. 2003. Mineral dust aerosol size distribution change during 
atmospheric transport. J. Geophys. Res. 108(D19), 8592, doi:10.1029/2002JD002536.

Meng, Z. and Lu, B. 2007. Dust events as a risk factor for daily hospitalization for respiratory and cardiovascular diseases in Minquin, China. Atmos. Environ. 41, 7048-7058.

Middleton, N. 1985. Effect of drought on dust production in the Sahel. Nature 316, 431-434.

Middleton, N., Yiallouros, P., Kleanthous, S., Kolokotroni, O., Schwartz, J. and co-authors. 2008. A 10-year time-series analysis of respiratory and cardiovascular morbidity in Nicosia, Cyprus: the effect of shortterm changes in air pollution and dust storms. Environ. Health 7, 39, doi:10.1186/1476-069X-7-39.

Moulin, C., Lamber, C. W., Dulac, F. and Dayan, U. 1997. Control of atmospheric exports of dust from North Africa by the North Atlantic oscillation. Nature 387, 691-694.

Moulin, C. and Chiapello, I. 2004. Evidence of the control of summer atmospheric transport of African dust over the Atlantic by Sahel sources from TOMS satellite (1979-2000). Geophys. Res. Lett. 31, L02107, doi:10.1029/2003GL018931.

Nickovic, S., Kallos, G., Papadopoulos, A. and Kakaliagou, O. 2001. A model for prediction of desert dust cycle in the atmosphere. $J$. Geophys. Res. 106, 18 113-18 129.

Page, E. S. 1954. Continuous inspection scheme. Biometrica 41(1/2), $100-115$.

Perez, C., Nickovic, S., Baldasano, J. M., Sicard, M., Rocadenbosch, F. and co-authors. 2006a. A long Saharan dust event over the western Mediterranean: Lidar, Sun photometer observations, and regional dust modeling. J. Geophys. Res. 111, D15214, doi:10.1029/2005JD006579.

Perez, C., Nickovic, S., Pejanovic, G., Baldasano, J. M. and Özsoy, E. 2006b. Interactive dust-radiation modeling: a step to improve weather forecasts. J. Geophys. Res. 111, D16206, doi:10.1029/2005JD006717.

Perez C., Jimenez, P., Jorba, O., Baldasano, J. M., Cuevas, E. and co-authors. 2007. Long-term simulations (1958-2006) of Saharan dust over the Mediterranean and the Eastern North Atlantic with the DREAM regional dust model, at IUGG 2007 Perugia, In: Proceedings of the Session of MSO04 Mineral Dust Cycle and its Impact on Clouds and Radiation (ICCP), Perugia, Italy, 2-13, July.

Prospero, J. M. and Nees, R. T. 1986. Impact of the North African drought and El Nino on mineral dust in the Barbados trade winds. Nature 320, 735-738.

Prospero, J. M. 1999. Long-term measurements of the transport of African mineral dust to the South eastern United States: implications for regional air quality. J. Geophys. Res. 104, 15 917-15 927.

Prospero, J. M., Ginoux, P., Torres, O., Nicholson, S. E. and Gill, T.
E. 2002. Environmental characterization of global sources of atmospheric soil dust identified with the nimbus 7 total ozonoe mapping sceptrometer (TOMS) absorbing aerosol product. Rev. Geophys. 40(1), 1002, doi:10.1029/2000RG000095.

Prospero, J. M. and Lamb, P. J. 2003. African droughts and dust transport to the caribbean: climate change implications. Science 302(7), 1024-1027.

Riemer, N., Doherty, O. M. and Hameed, S. 2006. On the variability of African dust transport across the Atlantic. Geophys. Res. Lett. 33, L13814, doi:10.1029/2006GL026163.

Rolph, G. D. 2003. Real-Time Environmental Applications and Display System (READY). NOAA Air Resources Laboratory. Silver Spring, MD. Available at: http://www.arl.noaa.gov/HYSPLIT.php. Last accessed 7 January 2011.

Shinn, E. A., Smith, G. W., Prospero, J. M., Betzer, P., Hayes, M. L. and co-authors. 2000. African dust and the demise of Caribbean coral reefs. Geophys. Res. Lett. 27(19), 3029-3032.

Siegel, S. and Castellan, N. J. 1988. Non-Parametric Statistics for the Behavioural Science. McGraw-Hill. New York, USA.

Student. 1908. The probable error of a mean. Biometrika 6, 1-25.

Sultan, B., Labadi, K., Gue'gan, J. F. and Janicot, S. 2005. Climate drives the Meningitis epidemics onset in West Africa. PloS Med. 2, 44-49.

Torres-Padrón, M. E., Gelado-Caballero, M. D., Collado-Sánchez, C., Siruela-Matos, V. F., Cardona-Castellano, P. J. and co-authors. 2002. Variability of dust inputs to the CANIGO zone. Deep Sea Res. II 49, 3455-3464.

Viana M., Querol, X., Alastuey, A., Cuevas, E. and Rodríguez, S. 2002. Influence of African dust on the levels of atmospheric particulates in the Canary Islands air quality monitoring network. Atmos. Environ. 36, 5861-5875.

Wang, N. 2005. Decrease trend of dust event frequency over the past 200 years recorded in the Malan ice core from the northern Tibetan Plateau. Chin. Sci. Bull. 50(24), 2866-2871.

Wang, X., Huang, J., Ji, M. and Higuchi, K. 2008. Variability of East Asia dust events and their long-term trend. Atmos. Environ. 42, 31563165.

WHO Regional Office for Europe. 2002. Health Impact Assessment of Air Pollution in the Eight Major Italian Cities. World Health Organization, Regional Office for Europe.

WHO. 2003. Health Aspects of Air Pollution with Particulate Matter, Ozone and Nitrogen Dioxide. World Health Organization. Bonn, Germany.

Worsley, K. J. 1979. On the Likelihood Ratio test for a shift in location of normal populations. J. Am. Stat. Assoc. 74(366), 365-367, doi: $10.2307 / 2286336$. 